\title{
THE EFFECT OF EXERCISE IN THE SUPINE POSITION ON PULMONARY VASCULAR DYNAMICS IN PATIENTS WITH LEFT-TO-RIGHT SHUNTS
}

\author{
By H. J. C. SWAN, HIRAM W. MARSHALL, AND EARL H. WOOD
}

(From the Section of Physiology, Mayo Clinic and Mayo Foundation, ${ }^{1}$ Rochester, Minn.)

(Submitted for publication July 9, 1957; accepted October 17, 1957)

The effect of exercise on pulmonary artery pressure, blood flow, and resistance has been studied extensively in normal subjects (1-5), and in patients with rheumatic heart disease $(6,7)$. However, only brief reports have appeared concerning the response of patients with intracardiac or great vessel shunts $(8,9)$. The dearth of published information probably is due in part to uncertainty as to the exact diagnosis in a sufficient number of cases. This paper concerns the changes in pulmonary and systemic blood flows, pressures, and resistances, and the associated variations in intracardiac or aortopulmonary shunts caused by leg exercise in the supine position in 30 patients with single congenital anomalies. In those patients with pulmonary hypertension the pulmonary blood flow was found to change only slightly during exercise irrespective of the magnitude of the left-toright shunt, while pulmonary artery pressure and pulmonary resistance values were increased. In patients without pulmonary hypertension there was a more definite increase in pulmonary blood flow; but as in the preceding group, a decrease was observed in the magnitude of the left-to-right shunt. Complete data for accurate anatomic appraisal had been obtained in all instances, and operative confirmation of the diagnosis was available in the great majority.

\section{METHODS AND MATERIALS}

Procedure. The following procedure was adhered to, with minor variations. The patient received 0.5 grain (30 mg.) of codeine and 1.5 grains of secobarbital (Seconal ${ }^{\circledR}$ ) immediately prior to the start of the procedure. He lay supine on a horizontally positioned fluoroscopy table. A No. 5 or 6 Cournand cardiac catheter (designated catheter 1) was introduced, usually by percutaneous needle puncture of a vein in the right antecubital fossa (10) and advanced to the heart. Oxy-

1 The Mayo Foundation, Rochester, Minnesota, is a part of the Graduate School of the University of Minnesota. gen saturations of blood samples obtained from various locations within the heart and great vessels were measured by a cuvette oximeter (11) to ascertain the oxygen saturation of the mixed venous blood and to determine the magnitude and location of the left-to-right shunt. The catheter tip was located in the main pulmonary artery, and a needle was inserted into a radial artery. Pressures in the systemic and pulmonary artery systems were recorded by means of strain-gauge manometers. It was desirable in a number of patients to obtain simultaneously samples of blood from the inferior vena cava as well as from the pulmonary artery. To make this possible a second catheter (designated catheter 2) was inserted and advanced directly into the inferior vena cava. The rate of oxygen consumption was then determined by collection of the expired air for five minutes in a largevolume, low-resistance plastic balloon. Analysis of the expired air was carried out immediately by the Haldane method. Midway during the period of collection of expired air, blood samples were obtained for analysis of the oxygen content by the method of Van Slyke and Neill (12) from the pulmonary artery and the radial artery, and from the inferior vena cava if a second catheter was being used. The oxygen capacity of hemoglobin was measured by the method of Sendroy (13), using the modification of Roughton, Darling, and Root (14). Immediately following the collection of the blood samples, a record of pulmonary and systemic artery pressures was obtained, and this record was considered to represent the resting state. The patient's legs then were elevated and his feet attached to the pedals of a bicycle ergometer (10) which was positioned at the end of the fluoroscopy table. The revolutions of the ergometer caused the deflection of a galvanometer needle which was visible to the patient and was recorded photographically. In keeping the needle at a predetermined position a constant speed of rotation of the exercycle was maintained. After an average of four and one-half minutes from the start of exercise, blood samples again were withdrawn simultaneously from the pulmonary artery and radial artery, and from the inferior vena cava if a second catheter were in position. During a one minute interval, starting at the beginning of this sampling period (average rate of respirations: 25 per minute), the expired air was collected, the volume measured, and the gas analyzed by the Haldane method.

In an attempt to determine systemic blood flow during exercise, a blood sample was taken via catheter 2 from the inferior vena cava. Then this catheter was withdrawn 
to the superior vena cava and a second sample was taken; both samples were analyzed by the Van Slyke and Neill method and the results were averaged to give a measure of the oxygen content of mixed venous blood.

In the patients with patent ductus arteriosus in whom catheter 2 was not inserted, the tip of catheter 1 was withdrawn to the outflow, or midportion, of the right ventricle, and a further sample obtained. In patients with ventricular septal defect, the catheter was withdrawn from the pulmonary artery to the midportion of the right atrium and a sample was obtained from there.

Four patients were studied while breathing oxygen via a low-resistance, small dead-space system from a spirometer which contained approximately 35 liters of a mixture of 95 per cent oxygen and 5 per cent nitrogen at equilibrium with the subject's respiratory gases, and which incorporated a carbon dioxide absorber. The oxygen consumption was determined from the decrease in the volume of gas in the spirometer 1) at rest for a period of three minutes, and 2) during exercise for a period of one minute, centered on the time of collection of blood samples for manometric analysis.

Recordings of pulmonary and systemic artery pressures and sometimes of inferior and superior vena caval pressures during exercise were obtained immediately after the sampling of blood for Van Slyke analyses. The exercise then was discontinued.

Calculations. Among the data to be reported, the major emphasis will be placed on the values of pulmonary blood flow, pulmonary artery pressure, and total pulmonary resistance. Calculated values of systemic blood flow, systemic artery pressure and systemic vascular re-

TABLE I

Vital statistics and measured values from Group A: 16 patients with left-to-right shunts and severe pulmonary hypertension

\begin{tabular}{|c|c|c|c|c|c|c|c|c|c|c|c|c|c|c|}
\hline \multirow[b]{3}{*}{$\begin{array}{l}\text { Case } \\
\text { no.* }\end{array}$} & \multirow[b]{3}{*}{$\begin{array}{l}\text { Age } \\
(y r .) \\
\text { and } \\
\text { sex }\end{array}$} & \multirow[b]{3}{*}{$\begin{array}{l}\text { Surface } \\
\text { area } \\
(\boldsymbol{M . 2})\end{array}$} & \multirow[b]{3}{*}{$\begin{array}{l}\text { Diagnosis, }+ \\
\text { duration of } \\
\text { exercise } \\
\text { (min.) }\end{array}$} & \multirow[b]{3}{*}{$\begin{array}{l}\text { Rest, } \\
\text { exer- } \\
\text { cise }\end{array}$} & \multirow[b]{3}{*}{$\begin{array}{c}\text { Oxygen } \\
\text { consump- } \\
\text { tion } \\
(m l . / m i n .)\end{array}$} & \multirow[b]{3}{*}{$\underset{(L . / \min .}{\mathrm{Q}_{\mathrm{p}} \ddagger}$} & \multirow[b]{3}{*}{$\begin{array}{c}Q_{s} \ddagger \\
n . / M .2)\end{array}$} & \multirow{3}{*}{\multicolumn{2}{|c|}{ 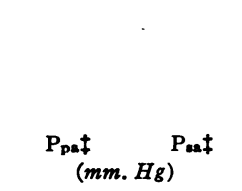 }} & \multirow{3}{*}{\multicolumn{2}{|c|}{ 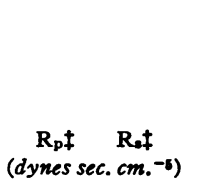 }} & \multicolumn{3}{|c|}{ Oxygen } \\
\hline & & & & & & & & & & & & \multirow[b]{2}{*}{$\begin{array}{c}\text { Hemo- } \\
\text { globin } \\
\text { capacity } \\
(m l . / 10\end{array}$} & \multicolumn{2}{|c|}{ Total content } \\
\hline & & & & & & & & & & & & & $\begin{array}{c}\text { Sys- } \\
\text { temic } \\
\text { artery } \\
O \mathrm{ml} \text { of } b l\end{array}$ & 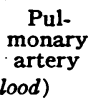 \\
\hline 1 & $\begin{array}{l}43 \\
\mathbf{M}\end{array}$ & 1.60 & VSD & $\underset{\mathbf{E}}{\mathbf{R}}$ & $\begin{array}{l}279 \\
878\end{array}$ & $\begin{array}{l}3.6 \\
5.3\end{array}$ & $\begin{array}{l}3.7 \\
6.5\end{array}$ & $\begin{array}{l}121 / 53 \\
169 / 79\end{array}$ & $\begin{array}{l}119 / 65 \\
173 / 93\end{array}$ & $\begin{array}{l}1,050 \\
1,030\end{array}$ & $\begin{array}{r}1,120 \\
910\end{array}$ & $\begin{array}{l}24.7 \\
25.7\end{array}$ & $\begin{array}{l}22.4 \\
21.3\end{array}$ & $\begin{array}{l}19.7 \\
15.3\end{array}$ \\
\hline 2 & $\mathbf{3 0}$ & 1.68 & $\operatorname{VSD}_{7}$ & $\stackrel{\mathbf{R}}{\mathrm{E}}$ & $\begin{array}{l}290 \\
768\end{array}$ & $\begin{array}{l}7.9 \\
7.3\end{array}$ & $\begin{array}{l}2.6 \\
4.9\end{array}$ & $\begin{array}{l}104 / 49 \\
133 / 56\end{array}$ & $\begin{array}{l}106 / 74 \\
147 / 78\end{array}$ & $\begin{array}{l}400 \\
530\end{array}$ & $\begin{array}{r}1,540 \\
960\end{array}$ & $\begin{array}{l}20.9 \\
20.7\end{array}$ & $\begin{array}{l}20.4 \\
19.4\end{array}$ & $\begin{array}{l}18.2 \\
14.1\end{array}$ \\
\hline 3 & M4 & 1.85 & $\underset{7}{\operatorname{VSD}}$ & $\begin{array}{l}\mathrm{R} \\
\mathrm{E}\end{array}$ & $\begin{array}{l}216 \\
650\end{array}$ & $\begin{array}{l}1.9 \\
2.4\end{array}$ & $\begin{array}{l}2.7 \\
3.6\end{array}$ & $\begin{array}{l}130 / 73 \\
175 / 104\end{array}$ & $\begin{array}{l}135 / 83 \\
175 / 108\end{array}$ & $\begin{array}{l}2,180 \\
2,270\end{array}$ & $\begin{array}{l}1,590 \\
1,550\end{array}$ & $\begin{array}{l}27.0 \\
27.4\end{array}$ & $\begin{array}{l}23.7 \\
18.3\end{array}$ & $\begin{array}{l}19.9 \\
12.4\end{array}$ \\
\hline 4 & $\stackrel{28}{\mathrm{M}}$ & 1.69 & $\underset{5}{A S D}$ & $\begin{array}{l}\mathrm{R} \\
\mathrm{E}\end{array}$ & $\begin{array}{l}266 \\
667\end{array}$ & $\begin{array}{l}3.3 \\
4.0\end{array}$ & $\begin{array}{l}1.6 \\
2.3\end{array}$ & $\begin{array}{r}93 / 47 \\
115 / 61\end{array}$ & $\begin{array}{r}96 / 68 \\
122 / 84\end{array}$ & $\begin{array}{l}890 \\
890\end{array}$ & $\begin{array}{l}2,840 \\
2,510\end{array}$ & $\begin{array}{l}23.6 \\
24.3\end{array}$ & $\begin{array}{l}22.7 \\
21.5\end{array}$ & $\begin{array}{l}18.6 \\
14.4\end{array}$ \\
\hline 5 & $\stackrel{14}{F}$ & 1.23 & $\operatorname{VSD}_{7}$ & $\stackrel{\mathbf{R}}{\mathrm{E}}$ & $\begin{array}{l}205 \\
493\end{array}$ & $\begin{array}{l}6.9 \\
6.7\end{array}$ & $\begin{array}{l}4.2 \\
5.8\end{array}$ & $\begin{array}{l}126 / 76 \\
152 / 84\end{array}$ & $\begin{array}{l}137 / 70 \\
165 / 82\end{array}$ & $\begin{array}{r}880 \\
1,040\end{array}$ & $\begin{array}{l}1,420 \\
1,240\end{array}$ & $\begin{array}{l}18.2 \\
18.7\end{array}$ & $\begin{array}{l}18.1 \\
17.9\end{array}$ & $\begin{array}{l}15.7 \\
12.8\end{array}$ \\
\hline 6 & $\stackrel{20}{\mathbf{M}}$ & 1.74 & $\operatorname{VSD}_{8}$ & $\underset{\mathrm{E}}{\mathrm{R}}$ & $\begin{array}{l}279 \\
865\end{array}$ & $\begin{array}{l}4.8 \\
4.9\end{array}$ & $\begin{array}{l}3.8 \\
6.8\end{array}$ & $\begin{array}{l}119 / 52 \\
167 / 78\end{array}$ & $\begin{array}{l}133 / 64 \\
165 / 84\end{array}$ & $\begin{array}{r}850 \\
1,010\end{array}$ & $\begin{array}{r}1,050 \\
790\end{array}$ & $\begin{array}{l}23.3 \\
24.0\end{array}$ & $\begin{array}{l}21.9 \\
19.1\end{array}$ & $\begin{array}{l}19.9 \\
13.7\end{array}$ \\
\hline 7 & $\stackrel{15}{\mathrm{~F}}$ & 1.22 & $\underset{4}{\text { VSD }}$ & $\underset{\mathrm{R}}{\mathrm{R}}$ & $\begin{array}{l}179 \\
680\end{array}$ & $\begin{array}{l}7.3 \\
8.4\end{array}$ & 3.7 & $\begin{array}{l}121 / 68 \\
151 / 86\end{array}$ & $\begin{array}{l}139 / 65 \\
176 / 79\end{array}$ & $\begin{array}{l}760 \\
840\end{array}$ & 1,600 & $\begin{array}{l}18.2 \\
18.7\end{array}$ & $\begin{array}{l}18.0 \\
17.4\end{array}$ & $\begin{array}{l}16.0 \\
11.9\end{array}$ \\
\hline 8 & $\mathbf{1 4}$ & 1.08 & $\underset{5 \frac{1}{2}}{A-V_{\text {canal }}}$ & $\underset{\mathrm{E}}{\mathrm{R}}$ & $\begin{array}{l}193 \\
551\end{array}$ & $\begin{array}{l}13.7 \\
15.1\end{array}$ & 2.7 & $\underset{8}{80 / 30}$ & $\begin{array}{r}96 / 54 \\
122 / 56\end{array}$ & $\begin{array}{l}250 \\
330\end{array}$ & 1,860 & $\begin{array}{l}17.5 \\
17.7\end{array}$ & $\begin{array}{l}16.7 \\
15.3\end{array}$ & $\begin{array}{l}16.2 \\
14.3\end{array}$ \\
\hline 9 & $\begin{array}{l}36 \\
\mathbf{M}\end{array}$ & 1.66 & $\underset{7}{\text { ASD }}$ & $\underset{\mathrm{R}}{\mathrm{R}}$ & $\begin{array}{l}225 \\
424\end{array}$ & $\begin{array}{l}2.2 \\
1.9\end{array}$ & $\begin{array}{l}2.4 \\
2.1\end{array}$ & $\begin{array}{r}75 / 40 \\
118 / 55\end{array}$ & $93 / 57$ & $\begin{array}{l}1,130 \\
1,930\end{array}$ & 1,380 & $\begin{array}{l}20.5 \\
21.9\end{array}$ & $\stackrel{18.3}{\|}$ & $\begin{array}{r}14.4 \\
8.5\end{array}$ \\
\hline 10 & $\stackrel{21}{\mathrm{~F}}$ & 1.54 & $\underset{5}{A S D}$ & $\underset{\mathrm{E}}{\mathrm{R}}$ & $\begin{array}{l}234 \\
563\end{array}$ & $\begin{array}{l}3.4 \\
3.7\end{array}$ & 3.2 & $\begin{array}{l}113 / 55 \\
148 / 64\end{array}$ & $\begin{array}{l}135 / 78 \\
163 / 83\end{array}$ & $\begin{array}{l}1,080 \\
1,320\end{array}$ & 1,570 & $\begin{array}{l}17.8 \\
18.0\end{array}$ & $\begin{array}{l}16.8 \\
13.0\end{array}$ & $\begin{array}{r}13.2 \\
7.6\end{array}$ \\
\hline 11 & M & 1.73 & $\underset{6}{A S D}$ & $\stackrel{\mathrm{R}}{\mathrm{E}}$ & $\begin{array}{l}273 \\
750\end{array}$ & $\begin{array}{l}3.7 \\
4.8\end{array}$ & $\begin{array}{l}2.8 \\
3.9\end{array}$ & $\begin{array}{c}74 / 3-7 \pi \\
104 / 8-139\end{array}$ & $\begin{array}{l}110 / 68 \\
134 / 80\end{array}$ & 450 & $\begin{array}{l}1,320 \\
1,150\end{array}$ & $\begin{array}{l}21.6 \\
22.4\end{array}$ & $\begin{array}{l}20.6 \\
20.1\end{array}$ & $\begin{array}{l}16.9 \\
13.3\end{array}$ \\
\hline 12 & $\frac{28}{F}$ & 1.74 & PDA & $\stackrel{\mathrm{R}}{\mathrm{E}}$ & $\begin{array}{l}246 \\
615\end{array}$ & $\begin{array}{l}5.9 \\
6.8\end{array}$ & $\begin{array}{l}2.9 \\
6.4\end{array}$ & $\begin{array}{r}86 / 55 \\
110 / 69\end{array}$ & $\begin{array}{l}135 / 65 \\
169 / 87\end{array}$ & $\begin{array}{l}510 \\
550\end{array}$ & $\begin{array}{r}1,400 \\
820\end{array}$ & $\begin{array}{l}19.6 \\
19.6\end{array}$ & $\begin{array}{l}19.1 \\
19.3\end{array}$ & $\begin{array}{l}16.7 \\
14.1\end{array}$ \\
\hline 13 & $\begin{array}{l}34 \\
\mathbf{M}\end{array}$ & 1.93 & $\underset{7}{A S D}$ & $\underset{\mathrm{E}}{\mathrm{R}}$ & $\begin{array}{l}208 \\
885\end{array}$ & $\begin{array}{l}7.2 \\
7.6\end{array}$ & 3.4 & $\begin{array}{r}76 / 34 \\
101 / 37\end{array}$ & $\begin{array}{l}120 / 68 \\
138 / 78\end{array}$ & $\begin{array}{l}280 \\
310\end{array}$ & 1,040 & $\begin{array}{l}21.9 \\
22.5\end{array}$ & $\begin{array}{l}21.5 \\
19.3\end{array}$ & $\begin{array}{l}20.0 \\
16.2\end{array}$ \\
\hline 14 & $\underset{F}{21}$ & 1.63 & $\underset{5}{P D A}$ & $\underset{\mathrm{E}}{\mathrm{R}}$ & $\begin{array}{l}286 \\
667\end{array}$ & $\begin{array}{r}11.7 \\
9.6\end{array}$ & $\begin{array}{l}4.0 \\
5.3\end{array}$ & $\begin{array}{r}78 / 50 \\
104 / 63\end{array}$ & $\begin{array}{l}162 / 57 \\
170 / 66\end{array}$ & $\begin{array}{l}250 \\
390\end{array}$ & $\begin{array}{r}1,120 \\
960\end{array}$ & $\begin{array}{l}15.1 \\
15.4\end{array}$ & $\begin{array}{l}15.5 \\
15.9\end{array}$ & $\begin{array}{l}14.0 \\
11.6\end{array}$ \\
\hline 15 & $\stackrel{44}{F}$ & 2.38 & $\underset{7}{\mathrm{PDA}}$ & $\underset{\mathrm{E}}{\mathrm{R}}$ & $\begin{array}{l}290 \\
924\end{array}$ & $\begin{array}{l}3.0 \\
4.2\end{array}$ & $\begin{array}{l}2.1 \\
3.5\end{array}$ & $\begin{array}{l}76 / 35 \\
88 / 56\end{array}$ & $\begin{array}{l}160 / 81 \\
200 / 106\end{array}$ & $\begin{array}{l}550 \\
540\end{array}$ & $\begin{array}{l}1,740 \\
1,320\end{array}$ & $\begin{array}{l}21.1 \\
22.5\end{array}$ & $\begin{array}{l}20.6 \\
21.9\end{array}$ & $\begin{array}{l}16.5 \\
12.7\end{array}$ \\
\hline 16 & $\begin{array}{l}33 \\
\mathbf{M}\end{array}$ & 1.73 & $\underset{6}{\mathrm{ASD}}$ & $\underset{\mathrm{E}}{\mathrm{R}}$ & $\begin{array}{l}258 \\
721\end{array}$ & $\begin{array}{l}4.7 \\
5.8\end{array}$ & 3.8 & $\begin{array}{l}60 / 26 \\
93 / 41\end{array}$ & $\begin{array}{l}140 / 67 \\
165 / 70\end{array}$ & $\begin{array}{l}360 \\
460\end{array}$ & 1,110 & $\begin{array}{l}13.9 \\
14.6\end{array}$ & $\begin{array}{l}13.3 \\
14.1\end{array}$ & $\begin{array}{r}10.1 \\
6.9\end{array}$ \\
\hline
\end{tabular}

* Cases arranged in order of decreasing pulmonary/systemic systolic pressure ratio at rest.

+ VSD = Ventricular septal defect. ASD = Atrial septal defect. A-V canal = Atrioventricular canal. PDA = Patent ductus arteriosus. $R_{\mathrm{s}}=$ pulmonary and systemic resistances.

Pulmonary artery mean pressure obtained.

Oxygen saturation of 80 per cent by ear oximeter used in calculations.

Right ventricular pressure. (Pulmonary artery pressure also obtained at rest.) 
TABLE II

Vital statistics and measured values from Group B: 14 patients with left-to-right shunts but not severe pulmonary hypertension

\begin{tabular}{|c|c|c|c|c|c|c|c|c|c|c|c|c|c|c|}
\hline \multirow[b]{3}{*}{$\begin{array}{l}\text { Case } \\
\text { no.* }\end{array}$} & \multirow[b]{3}{*}{$\begin{array}{l}\text { Age } \\
(y r .) \\
\text { and } \\
\text { sex }\end{array}$} & \multirow[b]{3}{*}{$\begin{array}{l}\text { Surface } \\
\text { area } \\
(M .2)\end{array}$} & \multirow[b]{3}{*}{$\begin{array}{l}\text { Diagnosis, }+ \\
\text { duration of } \\
\text { exercise } \\
\quad(\min .)\end{array}$} & \multirow[b]{3}{*}{$\begin{array}{l}\text { Rest, } \\
\text { exer- } \\
\text { cise }\end{array}$} & \multirow[b]{3}{*}{$\begin{array}{c}\text { Oxygen } \\
\text { consump- } \\
\text { tion } \\
(m l . / m i n .)\end{array}$} & \multirow[b]{3}{*}{$\underset{(L . / m i n .)}{Q_{p} \ddagger}$} & \multirow[b]{3}{*}{$\begin{array}{l}Q . \pm \\
\left.. M .{ }^{2}\right)\end{array}$} & \multirow[b]{3}{*}{$\begin{array}{l}\mathrm{Ppat}_{(m m} \\
\quad\end{array}$} & \multirow[b]{3}{*}{$\begin{array}{c}\text { Psat } \\
\mathrm{Hg})\end{array}$} & \multirow[b]{3}{*}{$\begin{array}{c}\mathbf{R}_{\mathbf{p}} \ddagger \\
\text { (dynes se }\end{array}$} & \multirow[b]{3}{*}{ 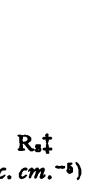 } & \multicolumn{3}{|c|}{ Oxygen } \\
\hline & & & & & & & & & & & & \multirow[b]{2}{*}{$\begin{array}{l}\text { Hemo- } \\
\text { globin } \\
\text { capacity } \\
\quad(m l . / 100\end{array}$} & \multicolumn{2}{|c|}{ Total content } \\
\hline & & & & & & & & & & & & & $\begin{array}{c}\text { Sys- } \\
\text { temic } \\
\text { artery } \\
0 \mathrm{ml} \text {. of } b\end{array}$ & $\begin{array}{c}\text { Pul- } \\
\text { monary } \\
\text { artery } \\
\text { blood) }\end{array}$ \\
\hline 17 & $\stackrel{43}{\mathrm{~F}}$ & 1.50 & $\underset{7}{\text { ASD }}$ & $\underset{\mathrm{E}}{\mathrm{R}}$ & $\begin{array}{l}212 \\
676\end{array}$ & $\begin{array}{l}16.0 \\
14.0\end{array}$ & 4.7 & $\begin{array}{l}32 / 10 \\
45 / 18\end{array}$ & $\begin{array}{l}134 / 64 \\
165 / 86\end{array}$ & $\begin{array}{l}60 \\
90\end{array}$ & 970 & $\begin{array}{l}17.7 \\
18.1\end{array}$ & $\begin{array}{l}17.7 \\
18.0\end{array}$ & $\begin{array}{l}16.8 \\
14.9\end{array}$ \\
\hline 18 & $\frac{48}{F}$ & 1.72 & $\underset{81}{A}$ & $\underset{\mathrm{R}}{\mathrm{R}}$ & $\begin{array}{l}226 \\
702\end{array}$ & $\begin{array}{l}11.9 \\
15.1\end{array}$ & 2.9 & $\begin{array}{l}40 / 19 \\
74 / 29\end{array}$ & $\begin{array}{l}184 / 101 \\
259 / 113\end{array}$ & $\begin{array}{l}100 \\
130\end{array}$ & 2.060 & $\begin{array}{l}17.3 \\
18.3\end{array}$ & $\begin{array}{l}17.1 \\
17.9\end{array}$ & $\begin{array}{l}16.0 \\
15.2\end{array}$ \\
\hline 19 & $\begin{array}{l}23 \\
\mathbf{M}\end{array}$ & 1.98 & $\underset{5}{\mathrm{ASD}}$ & $\underset{\mathrm{E}}{\mathrm{R}}$ & $\begin{array}{l}3058 \\
8068\end{array}$ & $\begin{array}{r}9.0 \\
10.4\end{array}$ & 2.8 & $\begin{array}{l}27 / 14 \\
30 / 12\end{array}$ & $\begin{array}{l}110 / 72 \\
124 / 77\end{array}$ & $\begin{array}{l}80 \\
70\end{array}$ & 1,150 & $\begin{array}{l}20.7 \\
21.0\end{array}$ & $\begin{array}{l}21.4 \\
22.1\end{array}$ & $\begin{array}{l}19.7 \\
18.2\end{array}$ \\
\hline 20 & $\underset{F}{25}$ & 1.59 & $\underset{8}{A S D}$ & $\frac{\mathrm{R}}{\mathrm{E}}$ & $\begin{array}{l}244 \\
690\end{array}$ & $\begin{array}{r}8.5 \\
11.7\end{array}$ & $\begin{array}{l}3.3 \\
7.2\end{array}$ & $\begin{array}{l}25 / 10 \\
54 / 19\end{array}$ & $\begin{array}{l}117 / 68 \\
147 / 80\end{array}$ & $\begin{array}{r}90 \\
140\end{array}$ & $\begin{array}{r}1,260 \\
710\end{array}$ & $\begin{array}{l}16.8 \\
17.2\end{array}$ & $\begin{array}{l}17.0 \\
17.3\end{array}$ & $\begin{array}{l}15.2 \\
13.6\end{array}$ \\
\hline 21 & $\begin{array}{l}18 \\
\mathrm{M}\end{array}$ & 1.68 & $\underset{6 \frac{1}{2}}{\operatorname{ASD}}$ & $\underset{\mathrm{E}}{\mathrm{R}}$ & $\begin{array}{l}289 \\
799\end{array}$ & $\begin{array}{l}7.5 \\
7.0\end{array}$ & 3.7 & $\begin{array}{l}25 / 10 \\
32 / 16\end{array}$ & $\begin{array}{l}118 / 75 \\
146 / 85\end{array}$ & $\begin{array}{r}95 \\
140\end{array}$ & 1,130 & $\begin{array}{l}18.7 \\
19.3\end{array}$ & $\begin{array}{l}18.9 \\
19.6\end{array}$ & $\begin{array}{l}16.6 \\
12.7\end{array}$ \\
\hline 22 & $\begin{array}{l}29 \\
\mathrm{~F}\end{array}$ & 1.74 & $\begin{array}{c}\text { PDA } \\
10\end{array}$ & $\stackrel{\mathbf{R}}{\mathrm{E}}$ & $\begin{array}{l}2658 \\
6158\end{array}$ & $\begin{array}{l}7.2 \\
6.2\end{array}$ & $\begin{array}{l}4.0 \\
4.8\end{array}$ & $\begin{array}{l}21 / 10 \\
15 / 10\end{array}$ & $\begin{array}{l}118 / 63 \\
135 / 68\end{array}$ & $\begin{array}{l}110 \\
100\end{array}$ & $\begin{array}{l}870 \\
650\end{array}$ & $\begin{array}{l}16.6 \\
16.6\end{array}$ & $\begin{array}{r}18.2 \\
17.9\end{array}$ & $\begin{array}{l}16.1 \\
12.2\end{array}$ \\
\hline 23 & $\frac{20}{F}$ & 1.63 & $\underset{10}{A S D}$ & $\begin{array}{l}\mathbf{R} \\
\mathrm{E}\end{array}$ & $\begin{array}{l}231 \\
582\end{array}$ & $\begin{array}{r}6.8 \\
10.0\end{array}$ & $\begin{array}{l}3.4 \\
6.1\end{array}$ & $\begin{array}{l}26 / 11 \\
35 / 18\end{array}$ & $\begin{array}{l}118 / 69 \\
152 / 84\end{array}$ & $\begin{array}{l}120 \\
110\end{array}$ & $\begin{array}{r}1,320 \\
850\end{array}$ & $\begin{array}{l}19.1 \\
19.5\end{array}$ & $\begin{array}{l}19.2 \\
20.0\end{array}$ & $\begin{array}{l}17.1 \\
16.5\end{array}$ \\
\hline 24 & $\underset{F}{62}$ & 1.66 & $\underset{8}{\mathrm{PDA}}$ & $\stackrel{\mathbf{R}}{\mathrm{E}}$ & $\begin{array}{l}244 \\
569\end{array}$ & $\begin{array}{l}6.1 \\
6.6\end{array}$ & $\begin{array}{l}3.1 \\
5.5\end{array}$ & $\begin{array}{l}57 / 32 \\
72 / 40\end{array}$ & $\begin{array}{l}200 / 80 \\
216 / 91\end{array}$ & $\begin{array}{l}310 \\
370\end{array}$ & $\begin{array}{l}1,780 \\
1,150\end{array}$ & $\begin{array}{l}17.8 \\
18.3\end{array}$ & $\begin{array}{l}17.8 \\
18.5\end{array}$ & $\begin{array}{l}15.4 \\
13.3\end{array}$ \\
\hline 25 & $\frac{47}{F}$ & 1.47 & $\underset{10}{\text { PDA }}$ & $\begin{array}{l}\mathrm{R} \\
\mathrm{E}\end{array}$ & $\begin{array}{l}2568 \\
5258\end{array}$ & $\begin{array}{l}6.7 \\
7.9\end{array}$ & $\begin{array}{l}3.1 \\
4.0\end{array}$ & $\begin{array}{l}24 / 12 \\
23 / 14\end{array}$ & $\begin{array}{l}166 / 81 \\
185 / 88\end{array}$ & $\begin{array}{l}190 \\
160\end{array}$ & $\begin{array}{l}2,010 \\
1,650\end{array}$ & $\begin{array}{l}18.1 \\
18.4\end{array}$ & $\begin{array}{l}20.0 \\
20.4\end{array}$ & $\begin{array}{l}17.4 \\
15.9\end{array}$ \\
\hline 26 & $\stackrel{23}{F}$ & 1.40 & $\mathrm{vSD}_{7}$ & $\stackrel{\mathrm{R}}{\mathrm{E}}$ & $\begin{array}{l}212 \\
769\end{array}$ & $\begin{array}{l}5.2 \\
8.2\end{array}$ & $\begin{array}{l}4.1 \\
6.8\end{array}$ & $\begin{array}{l}37 / 12 \\
44 / 15\end{array}$ & $\begin{array}{l}135 / 75 \\
133 / 65\end{array}$ & $\begin{array}{l}190 \\
170\end{array}$ & $\begin{array}{r}1,200 \\
740\end{array}$ & $\begin{array}{l}16.9 \\
17.3\end{array}$ & $\begin{array}{l}16.7 \\
17.4\end{array}$ & $\begin{array}{l}13.8 \\
10.7\end{array}$ \\
\hline 27 & $\stackrel{18}{M}$ & 1.44 & vsD & $\begin{array}{l}\mathrm{R} \\
\mathrm{E}\end{array}$ & $\begin{array}{l}247 \\
832\end{array}$ & $\begin{array}{l}5.2 \\
8.9\end{array}$ & $\begin{array}{l}3.4 \\
6.1\end{array}$ & $\begin{array}{l}26 / 11 \\
34 / 16\end{array}$ & $\begin{array}{l}132 / 64 \\
165 / 69\end{array}$ & $\begin{array}{l}220 \\
130\end{array}$ & $\begin{array}{r}1,630 \\
920\end{array}$ & $\begin{array}{l}20.1 \\
20.7\end{array}$ & $\begin{array}{l}20.1 \\
20.7\end{array}$ & $\begin{array}{l}16.8 \\
14.2\end{array}$ \\
\hline 28 & $\stackrel{17}{\mathrm{M}}$ & 1.66 & $\underset{9}{A S D}$ & $\stackrel{\mathrm{R}}{\mathrm{E}}$ & $\begin{array}{r}227 \\
1,149\end{array}$ & $\begin{array}{r}4.7 \\
10.0\end{array}$ & 3.5 & $\begin{array}{l}21 / 10 \\
47 / 25\end{array}$ & $\begin{array}{l}108 / 61 \\
158 / 85\end{array}$ & $\begin{array}{l}150 \\
150\end{array}$ & 1,060 & $\begin{array}{l}18.6 \\
19.5\end{array}$ & $\begin{array}{l}18.9 \\
19.2\end{array}$ & $\begin{array}{l}16.0 \\
12.3\end{array}$ \\
\hline 29 & $\stackrel{31}{M}$ & 1.96 & $\underset{9}{\text { PDA }}$ & $\begin{array}{l}\mathbf{R} \\
\mathbf{E}\end{array}$ & $\begin{array}{r}3048 \\
1,1238\end{array}$ & $\begin{array}{l}4.4 \\
8.3\end{array}$ & $\begin{array}{l}3.5 \\
6.0\end{array}$ & $\begin{array}{l}20 / 14 \\
32 / 19\end{array}$ & $\begin{array}{l}136 / 65 \\
147 / 73\end{array}$ & $\begin{array}{l}130 \\
110\end{array}$ & $\begin{array}{r}1.040 \\
650\end{array}$ & $\begin{array}{l}18.9 \\
19.6\end{array}$ & $\begin{array}{l}21.0 \\
20.9\end{array}$ & $\begin{array}{l}17.5 \\
14.0\end{array}$ \\
\hline 30 & $\begin{array}{l}14 \\
\mathbf{M}\end{array}$ & 1.42 & $\underset{6}{\text { PDA }}$ & $\stackrel{\mathbf{R}}{\mathrm{E}}$ & $\begin{array}{l}232 \\
667\end{array}$ & $\begin{array}{l}4.4 \\
6.3\end{array}$ & $\begin{array}{l}3.6 \\
5.8\end{array}$ & $\begin{array}{l}49 / 29 \\
53 / 25\end{array}$ & $\begin{array}{l}148 / 79 \\
158 / 81\end{array}$ & $\begin{array}{l}450 \\
340\end{array}$ & $\begin{array}{l}1,570 \\
1,040\end{array}$ & $\begin{array}{l}18.1 \\
18.3\end{array}$ & $\begin{array}{l}18.2 \\
18.4\end{array}$ & $\begin{array}{l}14.5 \\
11.0\end{array}$ \\
\hline
\end{tabular}

* Cases arranged in order of declining pulmonary blood flow values at rest (first reading recorded in $Q_{p}$ column).
+ ASD $=$ Atrial septal defect. PDA = Patent ductus arteriosus. VSD = Ventricular septal defect.

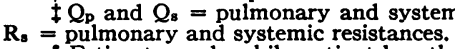

8 Estimate made while patient breathed 95 per cent oxygen.

sistance, and the magnitude of the intracardiac or great vessel shunts are reported also.

Pulmonary $\left(Q_{p}\right)$ and systemic $\left(Q_{s}\right)$ blood flows (liters per minute) were calculated by means of the Fick equation:

$$
Q_{p}=\frac{\dot{V}_{O_{2}}}{C_{p v}-C_{p s}}, \quad Q_{s}=\frac{\dot{V}_{O_{2}}}{C_{s a}-C_{m v}}
$$

where $\mathrm{V}_{\mathrm{O}_{2}}$ is the oxygen consumption in cubic centimeters (S.T.P.D.) per minute, and the several C's in the denominators represent the oxygen contents in cubic centimeters per liter of blood from pulmonary vein, pulmonary artery and systemic artery, and mixed venous blood, respectively. In those subjects studied while breathing air, if the oxygen saturation of systemic artery blood was less than 95 per cent, the oxygen content of pulmonary vein blood was taken to be 98 per cent of the oxygen capacity plus $0.3 \mathrm{ml}$. per $100 \mathrm{ml}$. of blood to account for oxygen in physical solution while the subject breathed air. When the oxygen saturation of systemic artery blood exceeded
95 per cent, it was assumed that no right-to-left shunt existed, and the content of pulmonary vein blood $\left(\mathrm{C}_{\mathrm{pr}}\right)$ was assumed to be equal to that of systemic artery blood $\left(\mathrm{C}_{\mathrm{sa}}\right)$. The oxygen content of mixed venous blood $\left(\mathrm{C}_{\mathrm{mv}}\right)$ was estimated in a different manner depending on the location of the left-to-right shunt as outlined previously. The assumptions pertaining to the use of such values will be discussed in detail in a later section.

The magnitudes of right-to-left $\left(S_{r-1}\right)$ and left-to-right $\left(S_{1-r}\right)$ shunts expressed as percentages, and the pulmonary $\left(R_{p}\right)$ and systemic $\left(R_{\mathbf{q}}\right)$ resistances (pressure-flow ratios) expressed as dynes second $\mathrm{cm}^{-5}$ were calculated in the manner of Cournand, Baldwin, and Himmelstein (15).

$$
\mathrm{S}_{1-\mathrm{r}}=\frac{\mathrm{C}_{\mathrm{pa}}-\mathrm{C}_{\mathrm{mv}}}{\mathrm{C}_{\mathrm{pv}}-\mathrm{C}_{\mathrm{mv}}} \times 100 \quad \mathrm{~S}_{\mathrm{r}-1}=\frac{\mathrm{C}_{\mathrm{pv}}-\mathrm{C}_{\mathrm{sa}}}{\mathrm{C}_{\mathrm{pv}}-\mathrm{C}_{\mathrm{mv}}} \times 100 .
$$

A left-to-right shunt is thus expressed as the fraction of pulmonary artery blood originating from the pulmonary veins, and the right-to-left shunt is expressed as the 
fraction of systemic artery blood originating from the cavae.

Patients. For this investigation 30 patients with single congenital intracardiac lesions characterized by left-toright shunt were studied. In a few with pulmonary hypertension a small right-to-left shunt also was demonstrable while the patient was at rest. Of the 30 patients, 8 had a patent ductus arteriosus, 8 had a ventricular septal defect, 13 had an atrial septal defect, and 1 had a persistent common atrioventricular canal.

\section{RESULTS}

These patients were divided into two groups according to the presence, Group A (Table I), or absence, Group B (Table II), of severe pulmonary hypertension. It is difficult to select a specific value for pulmonary artery pressure above which pulmonary hypertension exists and below which it does not. In some patients the size of a ventricular septal defect or a patent ductus arteriosus is the effective limit to the volume of a venoarterial shunt; in others the volume of pulmonary flow in relation to systemic flow is regulated chiefly by the response of the pulmonary vessels, and the size of the abnormal communication is not a major limiting factor. In this regard an apparently appropriate division between the patients in the present study was made by classifying those patients in whom the systolic pressure in the pulmonary artery at rest was $60 \mathrm{~mm}$. $\mathrm{Hg}$ or more as having severe pulmonary hypertension. Those patients in whom the pulmonary artery systolic pressure was less than this value were considered not to have severe elevation of pulmonary artery pressure. The use of an arbitrary division such as this may result in the incorrect categorization of certain patients; but in the present group at least it appears that no patient without pulmonary hypertension of a severe degree has been included in Group A, while only two patients in Group B had pulmonary artery systolic pressures at rest in excess of $40 \mathrm{~mm}$. $\mathrm{Hg}$.

Data obtained by Barratt-Boyes and Wood (5) from a group of 12 normal subjects studied under similar conditions are included for purposes of comparison.

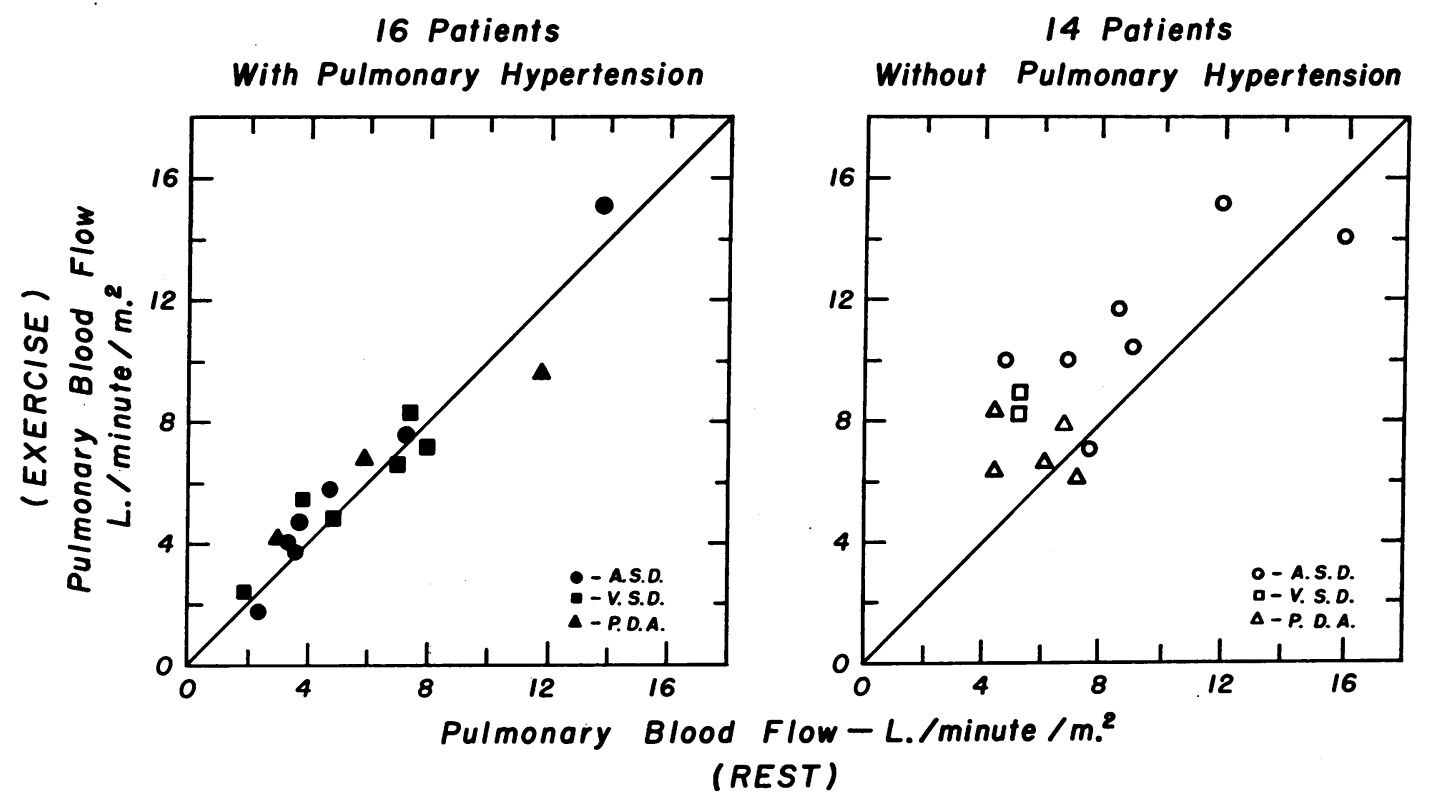

Fig. 1. The Relation of Pulmonary Blood Flow During Exercise and at Rest

The 16 patients with severe pulmonary hypertension (Group A) are depicted by the solid symbols (left), and the 14 without severe pulmonary hypertension (Group B) by the open symbols (right). The diagonal indicates the line of identity. Note the high correlation $(r=0.96)$ and close absolute agreement of the values in Group A. These data can be expressed in the form of a regression equation, $\mathrm{Y}=0.97+0.91 \mathrm{X}$, in which $\mathrm{X}$ and $\mathrm{Y}$ are values at rest and during exercise, respectively. The standard error of the coefficient of regression is 0.07 . Although there is a correlation between the values at rest and during exercise $(r=0.74)$ in Group $B$, it is less close than that in Group A. 


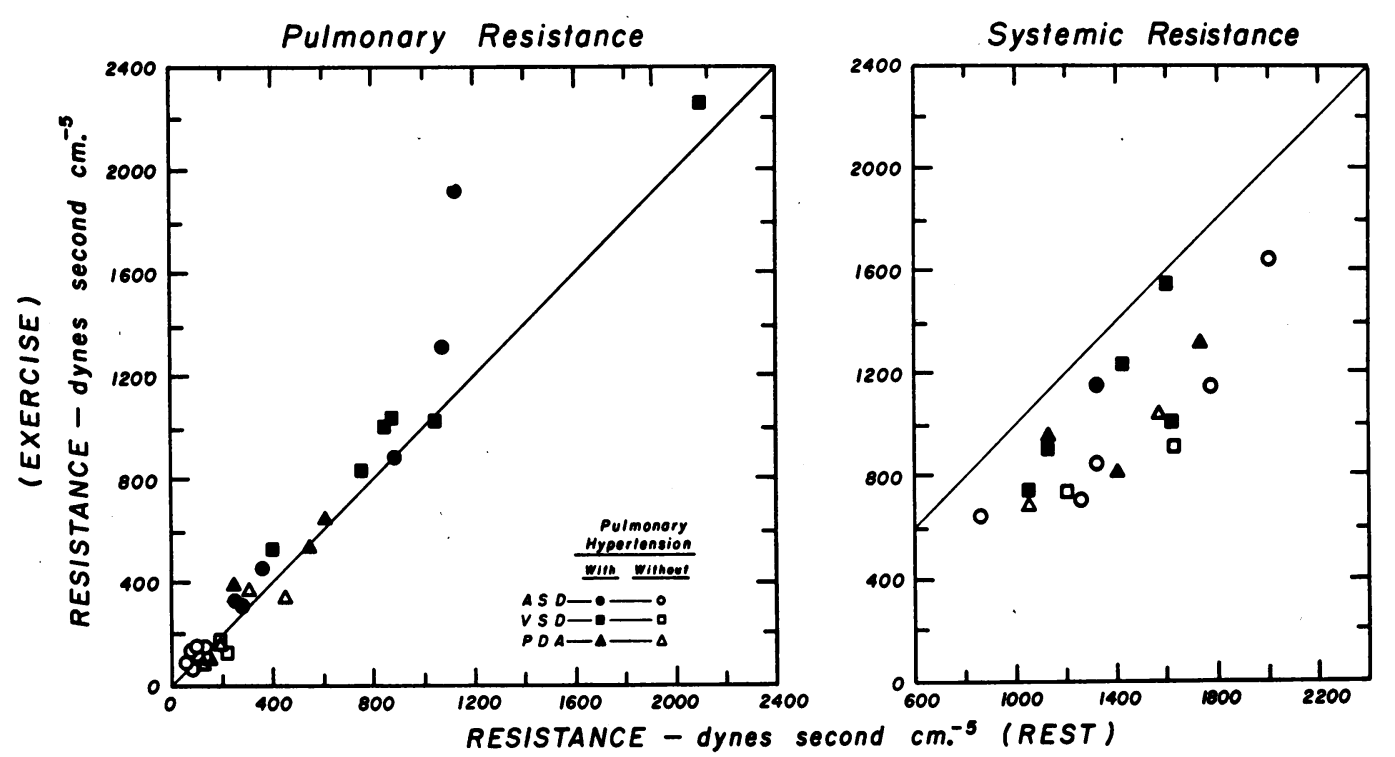

Fig. 2. The Relation of Pulmonary and Systemic Pressure flow Ratios (Vascular Resistances) Obtained During Exercise to Values Obtained at Rest

The solid symbols indicate the patients with severe pulmonary hypertension. Pulmonary resistance values for 29 patients are depicted in the left panel. Correlation between values during exercise to those at rest is high $(\mathrm{r}=0.96)$. The relationship can be expressed by the regression $\mathrm{Y}=-5+1.23 \mathrm{X}$, where $\mathrm{Y}$ and $\mathrm{X}$ are values during exercise and at rest, respectively. The standard error of the regression coefficient is \pm 0.09 .

Systemic resistance values for 19 patients are shown in the right panel. The correlation between the values is 0.70 , and the regression equation representing these data is $Y=83+0.83 \mathrm{X}$.

Oxygen consumption and pulmonary blood flow, pressure, and resistance

Patients with severe pulmonary hypertension (Group $A)$. The data for these patients are given in order of decreasing ratio of pulmonary to radial artery systolic pressures in Table $I$ and in Figures 1, 2, and 3 (solid symbols). The average values and changes are summarized in Table III. The average increase in oxygen consumption for this group was significantly less than for the normal subjects (Table III), due at least in part to the inability of certain patients (Cases 5, 9, 10, and 14 in Table I) to maintain leg exercise at the desired level. There is no difference of hemodynamic significance related to the nature of the anatomic lesion present. The small increase in pulmonary blood flow of 0.47 liter per minute per M. ${ }^{2}$ which occurs during exercise does not appear to be a change of remarkable hemodynamic consequence. The correlation of 0.96 with a slope of regression of 0.91 between the pulmonary blood flow at rest and during exercise demonstrates the pulmonary flow to be un- changed for practical purposes in these patients during exercise.

Pulmonary artery pressures were increased in all cases measured. The highest absolute values of pulmonary artery pressures and pulmonary resistances both at rest $(130 / 73 \mathrm{~mm}$. $\mathrm{Hg}, 2,180$ dynes second $\mathrm{cm}^{-5}$ ) and during exercise (175/ $104 \mathrm{~mm}$. $\mathrm{Hg}, 2,270$ dynes second $\mathrm{cm}^{-5}$ ) were obtained in Case 3 ; a slight decline in pulmonary resistance was seen in Case 15, the patient being a 44 year old woman with systemic hypertension and obesity in addition to patent ductus arteriosus.

Patients without severe pulmonary hypertension (Group B). The data for these patients are given in order of decreasing pulmonary blood flow in Table II and in Figures 1, 2, and 3 (open symbols). The average values and changes are summarized in Table III. The difference in oxygen consumption between the normal subjects and these patients was not significant.

The values for pulmonary blood flow during exercise are less well correlated $(r=0.74)$ with those obtained at rest than in Group A (Figure 
1 ), and the increase in flow of 1.83 liters per minute per $M .^{2}$ is highly significant $(p=0.001)$. Those patients in whom the resting pulmonary flow was less than 5.8 liters per minute per M. ${ }^{2}$ (that is, within the range of normal systemic flow for this laboratory) exhibited the greatest absolute and proportionate increase in blood flow. The changes in pulmonary artery pressure and pulmonary resistance are closely similar to the changes observed in the normal subjects.

\section{Systemic blood flow and systemic resistance}

In Group A, data for estimation of mixed venous blood were not obtained during exercise in three of the six cases of atrial septal defect, in one case of ventricular septal defect, nor in the patient with common atrioventricular canal. In Group B, no estimation of systemic blood flow was made during exercise in five of the seven cases of atrial septal defect. The average systemic blood flow
(Table III) at rest was identical for the patients in Group B and for normal subjects, and slightly less for the patients in Group A. Three patients (Case Nos. 4, 9, and 15) had values outside the lower range of normal (2.5 liters per minute per $\mathrm{M.}^{2}$ ). During exercise, the increase in systemic blood flow was somewhat less in Group A than in Group B or in the normal subjects. In both groups the changes in systemic artery pressure during exercise were similar to changes in the normal subjects.

The systemic resistance showed a diminution during exercise in both Group A and Group B, although it was of lesser magnitude in the former (Figure 2). In both groups the decline in systemic resistance was highly significant statistically.

\section{Intracardiac or great vessel shunts}

Intracardiac or great vessel shunts were calculated for all patients at rest and for the 11 patients
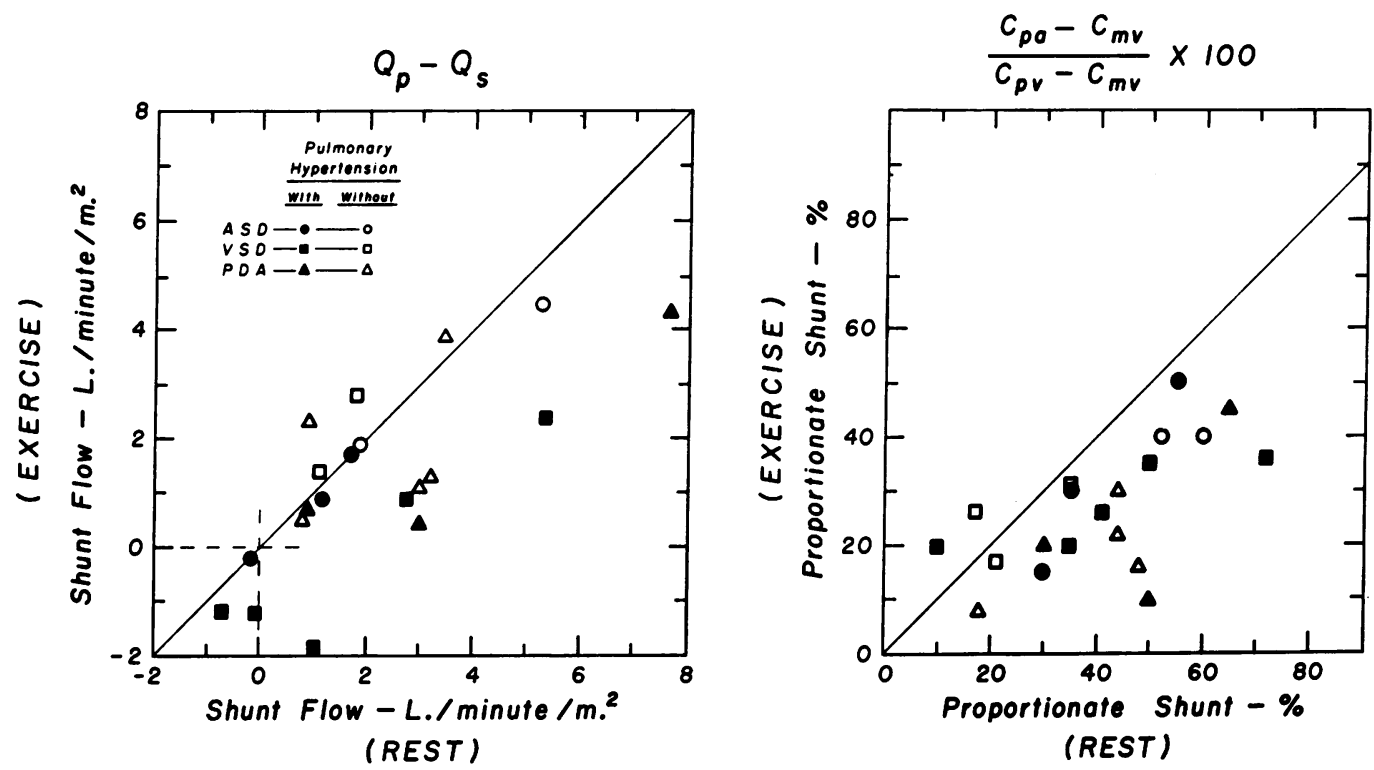

Fig. 3. Comparison of the Magnitude of Intracardiac or Great Vessel Shunts at Rest and During Exercise in 20 Patients

In the left panel the net shunt is expressed as the difference between pulmonary and systemic blood flows. Values to the left of and below the broken lines in the lower left corner indicate that systemic flow exceeds pulmonary flow and a net right-to-left shunt exists. Values to the right or above the broken lines indicate a net left-to-right shunt. Except in three patients (Cases 26, 27 and 29) with small communications, the volume of blood shunted in the left-to-right direction declined with exercise.

In the right panel the data are expressed as the proportion of pulmonary artery blood which is shunted in the left-to-right direction, and do not account for blood shunted right to left. All patients had a decline in the relative magnitude of the shunt on exercise except two. Of these, one patient (Case 29) had a small ventricular septal defect, and another (Case 3) had a large ventricular septal defect with severe pulmonary hypertension, and a shunt predominantly right to left both at rest and during exercise. 
TABLE III

Average values and standard deviations

\begin{tabular}{|c|c|c|c|c|c|c|c|c|c|c|c|}
\hline & & \multirow[b]{2}{*}{$\begin{array}{c}\text { Oxygen } \\
\text { consumption } \\
(m l . / m i n . / M .2)\end{array}$} & \multirow[b]{2}{*}{$\begin{array}{c}\text { Heart } \\
\text { rate } \\
\text { (beats/min.) }\end{array}$} & \multirow{2}{*}{\multicolumn{2}{|c|}{$\underset{\left(L . / \min . / M .2^{2}\right)}{\mathrm{Q}_{\mathfrak{p}}}$}} & \multicolumn{2}{|c|}{$\mathbf{P}_{\mathbf{p}}$} & \multicolumn{2}{|c|}{$\mathrm{Ps}_{\mathbf{s}}$} & \multirow[b]{2}{*}{$\underset{\text { (dynessec }}{\mathbf{R}_{\mathbf{p}}}$} & \multirow[b]{2}{*}{$\begin{array}{c}\mathbf{R}_{\mathbf{s}} \\
\left.\mathrm{cm} .^{-6}\right)\end{array}$} \\
\hline & & & & & & $\mathbf{s}$ & $\mathrm{D}_{(\mathrm{mm} . \mathrm{Hg})}$ & $\mathrm{s}$ & $\bar{D}$ & & \\
\hline \multicolumn{12}{|c|}{ Group A : 16 patients with pulmonary hypertension } \\
\hline $\begin{array}{l}\text { Rest } \\
\text { Exercise } \\
\text { Difference* }\end{array}$ & $\begin{array}{l}\text { Average } \\
\text { SD } \\
\text { Average } \\
\text { SD } \\
\text { Average } \\
\text { SD }\end{array}$ & $\begin{array}{r}148 \\
23 \\
416 \\
280 \\
+278 \\
65\end{array}$ & $\begin{array}{r}84 \\
17 \\
121 \\
21 \\
37 \\
23\end{array}$ & $\begin{array}{l}5.70 \\
3.30 \\
6.17 \\
3.16 \\
0.47 \\
0.93\end{array}$ & $\begin{array}{l}3.10 \\
0.64 \\
4.69 \\
1.47 \\
1.64 \\
1.20\end{array}$ & $\begin{array}{r}96 \\
23 \\
129 \\
29 \\
32 \\
10\end{array}$ & $\begin{array}{r}51 \\
14 \\
67 \\
18 \\
16 \\
8\end{array}$ & $\begin{array}{r}126 \\
21 \\
159 \\
22 \\
30 \\
12\end{array}$ & $\begin{array}{r}68 \\
8 \\
82 \\
13 \\
14 \\
9\end{array}$ & $\begin{array}{l}760 \\
500 \\
896 \\
578 \\
136 \\
226\end{array}$ & $\begin{array}{r}1,417 \\
229 \\
1,169 \\
367 \\
-255 \\
300\end{array}$ \\
\hline \multicolumn{12}{|c|}{ Group B: 14 patients without pulmonary hypertension } \\
\hline $\begin{array}{l}\text { Rest } \\
\text { Exercise } \\
\text { Difference* }\end{array}$ & $\begin{array}{l}\text { Average } \\
\text { SD } \\
\text { Average } \\
\text { SD } \\
\text { Average } \\
\text { SD }\end{array}$ & $\begin{array}{r}151 \\
22 \\
455 \\
112 \\
+304 \\
35\end{array}$ & $\begin{array}{r}81 \\
16 \\
115 \\
16 \\
35 \\
13\end{array}$ & $\begin{array}{l}7.34 \\
3.25 \\
9.17 \\
2.95 \\
1.83 \\
2.17\end{array}$ & $\begin{array}{l}3.50 \\
0.50 \\
5.81 \\
0.93 \\
2.31 \\
0.95\end{array}$ & $\begin{array}{l}31 \\
11 \\
42 \\
17 \\
11 \\
11\end{array}$ & $\begin{array}{r}15 \\
7 \\
20 \\
8 \\
5 \\
5\end{array}$ & $\begin{array}{r}137 \\
28 \\
164 \\
36 \\
26 \\
19\end{array}$ & $\begin{array}{r}73 \\
10 \\
82 \\
12 \\
9 \\
8\end{array}$ & $\begin{array}{r}164 \\
106 \\
158 \\
88 \\
-6 \\
50\end{array}$ & $\begin{array}{r}1,360 \\
383 \\
968 \\
327 \\
-506 \\
161\end{array}$ \\
\hline \multicolumn{12}{|c|}{12 normal subjects $\dagger$} \\
\hline $\begin{array}{l}\text { Rest } \\
\text { Exercise } \\
\text { Difference* }\end{array}$ & $\begin{array}{l}\text { Average } \\
\text { SD } \\
\text { Average } \\
\text { SD } \\
\text { Average } \\
\text { SD }\end{array}$ & $\begin{array}{r}141 \\
14 \\
479 \\
58 \\
+338 \\
63\end{array}$ & $\begin{array}{r}72 \\
10 \\
111 \\
15 \\
41 \\
10\end{array}$ & & $\begin{array}{l}3.50 \\
0.80 \\
5.70 \\
1.10 \\
2.10 \\
0.90\end{array}$ & $\begin{array}{r}21 \\
3 \\
31 \\
6 \\
10 \\
5\end{array}$ & $\begin{array}{r}11 \\
2 \\
15 \\
5 \\
4 \\
3\end{array}$ & $\begin{array}{r}148 \\
13 \\
177 \\
19 \\
29 \\
18\end{array}$ & $\begin{array}{r}77 \\
7 \\
86 \\
10 \\
9 \\
5\end{array}$ & $\begin{array}{r}189 \\
59 \\
162 \\
36 \\
-23 \\
35\end{array}$ & $\begin{array}{r}1,290 \\
265 \\
889 \\
59 \\
-370 \\
23\end{array}$ \\
\hline
\end{tabular}

* Exercise values minus values at rest.

$\dagger$ From another similar study by Barrett-Boyes and Wood (5).

in Group A and the 9 in Group B during exercise in whom the systemic blood flow had been estimated during exercise. In Figure 3 the shunt is expressed as the net volume of blood passing in the left-to-right direction $\left(Q_{p}-Q_{s}\right)$ and also as the proportion of blood traversing the pulmonary artery which has originated from the pulmonary vein. These values are of different significance in that the former is reduced by any volume of blood which may be shunted in the right-to-left direction and is expressed in absolute terms. In several cases the right-to-left shunt actually predominated and resulted in a negative value for the net shunt. A rough correlation exists between shunt values during rest and exercise as estimated by both methods.

For the patients with estimates of shunt both at rest and during exercise, the average net volumes of blood shunted left to right $\left(Q_{p}-Q_{s}\right)$ were 2.3 liters per minute per $\mathrm{M}^{2}$ at rest and 0.8 during exercise in Group A, as compared to 2.6 at rest and 2.4 liters per minute per $\mathrm{M}^{2}{ }^{2}$ during exercise in Group B. The differences between values at rest and during exercise were significant in Group A but not in Group B. Expressed as the proportions of pulmonary blood flow derived from pulmonary vein blood, the left-to-right shunts at rest averaged 44 and 46 per cent of pulmonary blood flow for Groups A and B, respectively, and showed a decline in each group during exercise to average values of 27 and 29 per cent (Figure 3 ). Among these 20 patients the changes were least in the five with atrial septal defects.

In 7 of the 16 cases in Group A, right-to-left shunts averaging 21 per cent (ranging from 10 to 40 per cent) of systemic blood flow were observed at rest. In the five with estimates both at rest and during exercise, the right-to-left shunt increased from an average value of 23 per cent to an average value of 34 per cent during exercise. In three additional patients in whom no right-to-left shunt was detected while the patient was at rest, rightto-left shunts averaging 12 per cent were demonstrable when the patient exercised. No right-toleft shunts were demonstrated for the patients in Group B.

\section{COMMENT}

Donald, Bishop, Cumming, and Wade (4) found in normal subjects that the major changes 
in both the oxygen consumption and the arteriovenous oxygen difference were virtually complete after two minutes of exercise, and they observed no further change in these variables when exercise was continued at the same level. Even in the majority of patients with rheumatic heart disease, the alterations in these variables are essentially complete after five minutes of exercise at a uniform rate, and the subject is in a steady state (6). The majority of our patients exercised for 7 to 12 minutes, and observations were made in the fourth to sixth minutes. For some of the more disabled patients the period of exercise was shorter, and observations were commenced at approximately two and one-half minutes and completed by the fourth or fifth minute. If a steady state had not been attained when observations were begun, significant changes would occur in the oxygen saturation of blood samples drawn during the period of observation of them. Measurement, therefore, was made of the continuous photographic record of the oxygen saturation of the blood during its withdrawal from the radial and pulmonary arteries through cuvette oximeters into syringes for manometric analysis, and the difference in oxygen saturation during the initial and the final 10 second periods of sampling was determined (Table IV). The interval between these periods was 20 to 35 seconds. The changes observed were usually very small and there was no consistent difference between the beginning and end of the sampling period. The greater variation observed occurred among patients in Group
B who had exercise for periods in excess of six minutes.

\section{Pulmonary blood flow measurement}

One of the main purposes of this study is to document the effect of exercise on pulmonary blood flow. If the estimate of oxygen consumption during the exercise period is assumed valid-and there is no reason to doubt this assumption-then the measurement of pulmonary flow depends on accurate values for the oxygen content of pulmonary vein and pulmonary artery blood.

The samples from the pulmonary artery and from a systemic artery always were drawn simultaneously. In all cases the assumption was made that there was no impairment of oxygenation of pulmonary capillary blood. No patients in Group B showed desaturation of systemic arterial blood during exercise. Furthermore, in a great majority of patients with cyanosis and intracardiac defects studied in this laboratory-including some patients in Group A while at rest-the quantitative estimates of right-to-left shunts by indicator techniques have agreed well with the estimates based on the oxygen saturation values, thus militating against desaturation of pulmonary vein blood as the basis for desaturation of systemic artery blood in such patients.

As for the oxygen content of pulmonary artery blood, it is usual to regard samples of blood withdrawn from the first chamber distal to the site of shunt as representing adequately the oxygen saturation of the blood entering the lungs. In the

TABLE IV

Differences between initial and later oxygen saturation values at rest and during exercise

\begin{tabular}{|c|c|c|c|c|}
\hline & \multicolumn{4}{|c|}{ Change in per cent of oxygen saturation* } \\
\hline & \multicolumn{2}{|c|}{ Rest } & \multicolumn{2}{|c|}{ Exercise } \\
\hline & $\begin{array}{l}\text { Radial } \\
\text { artery }\end{array}$ & $\begin{array}{l}\text { Pulmonary } \\
\text { artery }\end{array}$ & $\begin{array}{l}\text { Radial } \\
\text { artery }\end{array}$ & $\underset{\text { artery }}{\text { Pulmonary }}$ \\
\hline \multicolumn{5}{|l|}{ Group A } \\
\hline $\begin{array}{l}\text { Average change } \\
\text { Range }\end{array}$ & $\begin{array}{c}0 \\
(+1.5 \text { to }-0.6)\end{array}$ & $(+0 . \overline{5}$ to -1.1$)$ & $\left(+0.7^{-0.15}\right.$ to -1.0$)$ & $(+0.5$ to -1.0$)$ \\
\hline \multicolumn{5}{|l|}{ Group B } \\
\hline $\begin{array}{l}\text { Average changet } \\
\text { Range }\end{array}$ & $(+0.2$ to -1.3$)$ & $(+0 . \overline{7}$ to -1.8$)$ & $\begin{array}{c}+0.13 \\
(+1.0 \text { to }-0.8)\end{array}$ & $\begin{array}{c}+0.22 \\
(+4.6 \text { to }-3.5)\end{array}$ \\
\hline
\end{tabular}

* Saturation values measured by cuvette oximeter and recorded over periods of 40 to 55 seconds as samples were drawn at rest and in the fourth to sixth minutes of exercise.

$\dagger$ Mean value for final 10 seconds of blood flow minus mean value for initial 10 seconds of blood flow. 
cases of patent ductus arteriosus studied in this laboratory, the oxygen saturation of blood samples obtained from different locations in the right and left pulmonary arteries has been strikingly uniform, which implies that mixing of blood occurs to a sufficient degree in the pulmonary artery so that a sample of pulmonary artery blood is representative of all the blood entering the lungs.

\section{Calculation of systemic blood flow and intracardiac and great vessel shunts}

A major difficulty was the determination of an accurate value for mixed venous blood. In this study potential errors in the estimation of oxygen content of mixed venous blood during exercise would appear to be smallest in the eight cases of patent ductus arteriosus in which the blood samples were obtained from the outflow, or midportion, of the right ventricle, and greatest in the five cases of atrial septal defect in which samples of blood were obtained from the inferior and superior venae cavae (Table V). Data obtained in Case 18 also are included in this table, but calculations of systemic blood flow and intracardiac shunts were not made because examination of a roentgenogram taken at the time of sampling intended to be from the inferior vena cava clearly showed the catheter tip to be in an hepatic vein. Calculation of the systemic blood flow was not attempted in the remaining seven cases of atrial septal defect. In Cases 4, 9, and 11 the wide differences between arterial and venous blood and the relatively small differences between inferior and superior caval blood serve to reduce potential errors. In Case 20 the possibility of preferential sampling of he-

TABLE V

Six patients with atrial septal defect

\begin{tabular}{|c|c|c|c|c|}
\hline \multirow{3}{*}{$\begin{array}{l}\text { Case } \\
\text { No. }\end{array}$} & \multicolumn{4}{|c|}{$\begin{array}{l}\text { Oxygen saturation } \\
\text { (per cent) }\end{array}$} \\
\hline & \multicolumn{2}{|c|}{ Rest } & \multicolumn{2}{|c|}{ Exercise } \\
\hline & IVC* & svC & IVC* & svC $†$ \\
\hline $\begin{array}{r}4 \\
9 \\
11 \\
18 \\
20 \\
23\end{array}$ & $\begin{array}{l}60 \\
65 \\
74 \\
80 \\
78 \\
83\end{array}$ & $\begin{array}{l}53 \\
59 \\
66 \\
74 \\
68 \\
76\end{array}$ & $\begin{array}{l}18 \\
37 \\
37 \\
74 \ddagger \\
71 \\
60\end{array}$ & $\begin{array}{l}21 \\
42 \\
47 \\
47 \\
60 \\
85\end{array}$ \\
\hline
\end{tabular}

* IVC $=$ Inferior vena cava.

$\dagger$ SVC = Superior vena cava.

¥ Catheter tip in hepatic vein during exercise. patic vein blood is suggested by the higher saturation of inferior caval blood compared to superior caval blood, whereas in Case 23 the relatively small arteriovenous difference associated with a considerable superior-inferior caval difference makes possible a large error. To test this further, for these five cases the magnitude of the left-to-right shunt during exercise was recalculated using the lowest saturation value obtained to represent mixed venous blood. On the average, a decline in the shunt was still present even in this more extreme circumstance.

As a further test of the validity of the calculations of systemic blood flow, the relation of the increase in blood flow to the increase in oxygen consumption during exercise was examined. In Case 20 the calculated increase in blood flow was $1,300 \mathrm{ml}$. per minute for each $100 \mathrm{ml}$. per minute of increase in oxygen consumption, and in Case 23 the corresponding increase was $1,200 \mathrm{ml}$. per minute. These values greatly exceed the average of $626 \pm 217 \mathrm{ml}$. per minute obtained in the normal subjects. In the complete series of patients, four cases (Nos. 12, 20, 23, and 24) produced calculated systemic blood flow values which were disproportionate to the increase in oxygen consumption. Exclusion of these four cases would alter the reported increase in systemic blood flow during exercise by only 0.10 liter per minute per M. $^{2}$ in Group A, and 0.21 liter per minute $\mathrm{M}^{2}{ }^{2}$ in Group $B$, and would not alter the significance of the decline in left-to-right shunt which occurred during exercise. While the considerations just presented weaken the quantitative evaluation of figures for systemic blood flow and shunt obtained during exercise, the directional changes already suggested appear valid.

\section{Changes in pulmonary vascular dynamics}

Patients with pulmonary hypertension. The close relation between pulmonary blood flow values obtained at rest and during exercise deserves further comment. In the presence of pulmonary hypertension, the pulmonary blood flow appears to be relatively fixed (Figure 1), although a small increase was demonstrated during exercise. Bruce and John (8) reported that arterial desaturation occurred in two of their patients, but they did not report a fixed pulmonary blood flow. It 
is not possible to state that the increase in calculated resistance represents a change in the pulmonary blood vessels; however, the small change in left atrial flow with exercise makes changes in left atrial pressure unlikely. The analogy of changes in pulmonary blood vessels to the behavior of a linear potentiometer in a simple D.C. circuit may be quite misleading in instances such as these; here the impedance of a frequency dependent complex circuit may in fact be the more appropriate model.

As would be expected, apart from Case 4, in which evidence of cardiac failure was present, the systemic vascular resistance declined during exercise in every patient in whom the comparative measurements were made, and to about the same degree as in normal subjects. Difficulties of estimation of systemic blood flow notwithstanding, these data clearly indicate the difference in the responses of the pulmonary and systemic circulations produced by muscular activity.

The direction and magnitude of a shunt through a large ventricular septal defect or a patent ductus arteriosus are determined principally by the relative resistances offered by the pulmonary and systemic circulations to the flow of blood from the ventricles. A useful expression of these relative resistances is a ratio of pulmonary to systemic resistance, which minimizes the effect of nonspecific factors such as body size and allows comparison from subject to subject. In this group of patients, the average resistance ratio of 0.50 at rest was increased to 0.74 during exercise, owing mainly to the fall in systemic resistance. In cases with severe pulmonary hypertension and a level of pulmonary blood flow not above the range of normal while at rest (example: Case 6), the change in the pulmonary/systemic resistance ratio during exercise may result in a shunt predominantly in the right-to-left direction. The data suggest that cases of atrial septal defect with pulmonary hypertension may respond in a somewhat similar fashion; presumably there may be impedance of right ventricular filling due to a raised right ventricular diastolic pressure consequent on the increased pulmonary resistance. Alternatively, facilitation of left ventricular filling may be a result of the lowered systemic vascular resistance.

Patients without severe pulmonary hypertension. In the patients of Group B there was a definite increase in pulmonary blood flow during exercise as compared to that during rest, but in no patient did it rise to the level reported by Bruce and John (8) for upright walking. As in Group A, a lesser proportion of pulmonary blood flow is composed of pulmonary vein blood during exercise in cases with a large increase in resting pulmonary flow. In those cases with a small patent ductus arteriosus or ventricular septal defect, the size of the abnormal communication and the left ventricular or aortic pressure should logically be the principal determinants of the small shunt that occurs. The absolute and even the relative magnitude of the shunt has been demonstrated to increase during exercise in such cases.

\section{General interpretations}

Excluding those patients without pulmonary hypertension and without a shunt of functional significance in the left-to-right direction, the general response of the pulmonary vascular bed to exercise in the supine position appears to permit but a small increase in pulmonary blood flow, with an increase in pulmonary resistance in those patients who have pulmonary hypertension. There is usually a concomitant decrease in the absolute and relative magnitude of the left-to-right shunt, apparently related to the large decrease in the systemic vascular resistance which occurs uniformly during exercise. The consequences of these responses are of some significance, since it is clear that patients with large left-to-right shunts may adapt to the circulatory needs of exercise without major change in pulmonary vascular dynamics. During activity, the useful work of the right ventricle appears to be increased in that a greater absolute and relative amount of the output of this chamber is composed of systemic venous blood. This may explain the relatively poor correlation of physical development and exercise tolerance of many patients with congenital heart disease on the one hand, with the degree of alteration in circulatory dynamics when such patients are studied in the supine position on the other. In certain of the more disabled patients with severe pulmonary hypertension, this response may circumvent a stress of potentially fatal magnitude on the circulation such as does occur in the postoperative period following closure of patent 
ductus arteriosus without relief of severe pulmonary hypertension (16).

These responses produce in general a favorable situation for patients with left-to-right shunts, since the demands on the heart for an increase in systemic blood flow to meet the requirements of exercise are met without a concomitant increase in stress on those portions of the central circulation already overburdened by the presence of the abnormal shunt.

\section{SUMMARY}

1. The changes in pulmonary vascular dynamics associated with exercise in the supine position were studied in 30 patients with intracardiac or aortopulmonary left-to-right shunt. The patients were subdivided into Group A, whose pulmonary artery systolic pressures exceeded $60 \mathrm{~mm}$. $\mathrm{Hg}$ at rest, and Group B, whose pulmonary artery systolic pressures at rest were less than $60 \mathrm{~mm}$. $\mathrm{Hg}$. Group A was composed of seven patients with atrial septal defect (including one with common atrioventricular canal), six with ventricular septal defect, and three with patent ductus arteriosus; Group B was composed of seven patients with atrial septal defect, two with ventricular septal defect, and five with patent ductus arteriosus.

2. The pulmonary blood flow averaged 5.70 liters per minute per M. ${ }^{2}$ for Group $A$ at rest, and increased to 6.17 liters per minute per $\mathrm{M}^{2}$ during exercise. There was a strong correlation $(r=$ $0.96)$ between the flow values at rest and during exercise. For Group B the average pulmonary blood flow at rest of 7.34 liters per minute per M. ${ }^{2}$ was increased to 9.17 liters per minute per M. ${ }^{2}$ during exercise; but the correlation was less close $(\mathrm{r}=0.74)$ than for Group A.

3. Pulmonary artery pressure was increased during exercise in both groups. The pulmonary resistance was significantly elevated in Group A from an average value of 760 dynes second $\mathrm{cm}^{-5}$ at rest to 896 dynes second $\mathrm{cm}^{-5}$ during exercise. In contrast, there was no consistent increase in pulmonary resistance during exercise in Group B. Absence of data concerning pulmonary artery wedge (left atrial) pressure precludes a precise statement as to changes in pulmonary arteriolar resistance.

4. Systemic blood flows were calculated in 20 of the patients during exercise. The increase in systemic blood flow during muscular activity was greater than the increase in pulmonary blood flow. In contrast to the increase in pulmonary resistance in Group A, the normal decline in systemic vascular resistance associated with exercise was observed in both groups.

5. The average magnitude of left-to-right shunts declined in Group A from 44 per cent of the pulmonary blood flow at rest to 27 per cent during exercise, and in Group B from 46 per cent to 29 per cent. In seven patients, right-to-left shunts were present at rest, and these shunts increased in magnitude during exercise in the five patients from whom quantitative data were obtained during the latter state. In three other patients, right-to-left shunts developed during exercise, although no such shunt was detected at rest.

6. The differing responses of the pulmonary and the systemic circuits to exercise are considered to be the underlying basis for the relatively small change in pulmonary flow during exercise in patients with large defects. In consequence, the increased demands placed on the heart during exercise are met with relatively little additional stress on those parts of the circulation already overburdened by the presence of the left-to-right shunt.

\section{REFERENCES}

1. Riley, R. L., Himmelstein, A., Motley, H. L., Weiner, H. M., and Cournand, A. Studies of the pulmonary circulation at rest and during exercise in normal individuals and in patients with chronic pulmonary disease. Amer. J. Physiol. 1948, 152, 372.

2. Hickam, J. B., and Cargill, W. H. Effect of exercise on cardiac output and pulmonary arterial pressure in normal persons and in patients with cardiovascular disease and pulmonary emphysema. J. clin. Invest. 1948, 27, 10.

3. Dexter, L., Whittenberger, J. L., Haynes, F. W., Goodale, W. T., Gorlin, R., and Sawyer, C. G. Effect of exercise on circulatory dynamics of normal individuals. J. appl. Physiol. 1951, 3, 439.

4. Donald, K. W., Bishop, J. M., Cumming, G., and Wade, O. L. The effect of exercise on the cardiac output and circulatory dynamics of normal subjects. Clin. Sci. 1955, 14, 37.

5. Barratt-Boyes, B. G., and Wood, E. H. Hemodynamic response of healthy subjects to exercise in the supine position while breathing oxygen. J. appl. Physiol. 1957, 11, 129.

6. Ferrer, M. I., Harvey, R. M., Cathcart, R. T., Cournand, A., and Richards, D. W., Jr. Hemodynamic studies in rheumatic heart disease. Circulation 1952, 6, 688. 
7. Donald, K. W., Bishop, J. M., and Wade, O. L. A study of minute to minute changes of arteriovenous oxygen content difference, oxygen uptake and cardiac output and rate of achievement of a steady state during exercise in rheumatic heart disease. J. clin. Invest. 1954, 33, 1146.

8. Bruce, R. A., and John, G. G. Effects of upright posture and exercise (grade walking) on pulmonary hemodynamics in patients with left-to-right shunts (abstract). Circulation 1956, 14, 916.

9. Swan, H. J. C., Marshall, H. W., and Wood, E. H. The effect of exercise on the pulmonary blood flow in patients with left-to-right shunts (abstract). J. Lab. clin. Med. 1956, 48, 949.

10. Wood, E. H. Special technics of value in the cardiac catheterization laboratory. Proc. Mayo Clin. 1953, 28,58 .

11. Wood, E. H. Oximetry in Medical Physics, Otto Glasser, Ed. Chicago, The Year Book Publishers, Inc., 1950, vol. 2, pp. 664-680.
12. Van Slyke, D. D., and Neill, J. M. The determination of gases in blood and other solutions by vacuum extraction and manometric measurement. I. J. biol. Chem. 1924, 61, 523.

13. Sendroy, J., Jr. Manometric determination of hemoglobin by the oxygen capacity method. J. biol. Chem. 1931, 91, 307.

14. Roughton, F. J. W., Darling, R. C., and Root, W. S. Factors affecting determination of oxygen capacity, content and pressure in human arterial blood. Amer. J. Physiol. 1944, 142, 708.

15. Cournand, A., Baldwin, J. S., and Himmelstein, A. Cardiac Catheterization in Congenital Heart Disease: A Clinical and Physiological Study in Infants and Children. New York, The Cornmonwealth Fund, 1949.

16. Ellis, F. H., Jr., Kirklin, J. W., Callahan, J. A., and Wood, E. H. Patent ductus arteriosus with pulmonary hypertension: An analysis of cases treated surgically. J. thorac. Surg. 1956, 31, 268. 